\title{
Experimental investigations on CRDI diesel engine fuelled with acid oil methyl ester (AOME) and its blends with ethanol
}

\author{
S. Rajesh ${ }^{1}$, B. M. Kulkarni ${ }^{2}$, S. Kumarappa ${ }^{3}$, N. R. Banpurmath ${ }^{4}$ \\ ${ }^{1,3}$ Department of Mechanical Engineering, Bapuji Institute of Engineering \& Technology, Davangere - 577 004, Karnataka, INDIA \\ ${ }^{2}$ Department of Chemical Engineering, Bapuji Institute of Engineering \& Technology, Davangere - 577 004, Karnataka, INDIA, \\ ${ }^{4}$ Department of Mechanical Engineering, B.V. Bhoomaraddi College of Engineering and Technology, Hubballi, Karnataka 580031, INDIA \\ Corresponding author: nr_banapurmath@rediffmail.com
}

\begin{abstract}
Biodiesel which is propelled as substitute to diesel fuel though attractive is not viable at present state because of its high production cost with the major concern of finding a permanent resource. As basically biodiesel is a assortment of fatty acid methyl ester it can also be produced from non-glyceride sources like acid oil which is non-edible, easily obtainable in significant amounts at the majority of the vegetable oil processing plants. This paper mainly focuses on the utilization of Acid Oil Methyl Ester (AOME) and its combinations with diesel and ethanol in different proportionsin a modified diesel engine fitted with Common Rail Direct Injection (CRDI) facilities. Acid oil was suitably trans-esterified to obtain its ester AOME and was subsequently blended with diesel and ethanol and characterization of the obtained fuels were done. A functional single cylinder diesel engine was duly converted to CRDI engine in which Conventional Mechanical Fuel Injection System (CMFIS) was replaced with CRDI facilities in order to inject biodiesel at higher injection pressures. Experiments were conducted to examine the influence of Injection Timing (IT), and Injector opening Pressure (IP) on the performance of modified CRDI engine fuelled with AOME and its blends with diesel and ethanol for improved engine performance. The experimental examination revealed IT of $10^{\circ} \mathrm{bTDC}$ as well as IP of $900 \mathrm{bar}$ as the most excellent engine operating parameters to achieve the highest Brake Thermal Efficiency (BTE) with lowered Hydro-Carbon (HC), Carbon Monoxide (CO), smoke emissions while, oxides of nitrogen (NOx) emissions were found to be superior for the fuel combinations employed in the investigation.
\end{abstract}

Keywords: Diesel, Ethanol, Acid oil methyl ester (AOME), Common Rail Direct Injection (CRDI), Emissions.

DOI: http://dx.doi.org/10.4314/ijest.v9i1.6

\section{Introduction}

Over the last few decades continued effort has been made to reduce the usage of fossil fuel based petroleum fuels in all the sectors like agriculture, automobile and power generation applications. Concerns to address these issues have led research on renewable fuels and their utilization for compression ignition engine applications. This renewed interest in engine research and development of internal combustion engines on the whole and diesel engines above all with potential of complying with the emission standards of Bharat step and EURO standards are a necessity in the current dispensation. Amongst the projected substitute fuels biodiesel, ethanol and their combinations with diesel have witnessed a large amount of awareness in the current period for diesel engine applications. Biodiesel as well as ethanol are capable of being manufactured from various feed-stocks, which are commonly regarded as being renewable. Investigations on the employment of biodiesel in diesel engines have reported substantial increase in thermal efficiency as well as lessening in emissions (Hulwan et al., 2011). It may be noted that biodiesels have higher viscosity nearly twice the diesel and hence they need to be injected at higher injection pressure. Several investigations have been undertaken to check feasibility studies on the utilization of biodiesels for their use in CRDI engines.

In CRDI engines fuel can be injected with high injection pressures (IP) of equal to 2500 bar which enables to atomize fuel into extremely better drops (Pundir et al., 2007). Elevated velocity of fuel spray as a result of elevated IP breaks into the Combustion 
Chamber (CC) in the space of a brief period to completely make use of the compressed air. When pilot fuels are injected with high injection pressures in engine cylinder several benefits will be obtained with respect to enhanced engine performance and reduced emissions (Wloka et al., 2010, 2011). Researchers reported improved spray penetration at higher IP (Pan et al., 2012, Lensik et al, 2013). CRDI engine energized with both diesel as well as biodiesel formed less significant smoke as a result of the improved atomization of the fuel at superior IP and yielded an enhanced combustion owing to enhanced air-fuel combination as well as soot oxidation was improved as a result of elevated cylinder temperatures, according to literature account. A local enhancement of fueloxygen proportion in the course of the burning practice condensed the smoke emission for the reason of the oxygen molecular composition as well as the non-existence of aromatic as well as sulfur compounds in biodiesel fuel (Octavia et al., 2006). At an Injection Timing (IT) of 10 to $5^{\circ} \mathrm{bTDC}$ the combustion happened nearer to TDC which yielded the utmost thermal efficiency because of appropriate combination of fuel together with air as well as superior fuel atomization (Monyem et al., 2001, Senatore et al., 2008). The $\mathrm{HC}$ emissions lessened at IT from $10^{\circ}$ to $5^{\circ} \mathrm{bTDC}$, where BTE was superior (Carlo et al., 2002). The less significant fuel drops attained at superior IP enhanced the fuel combination with the combustion chambers' inside air, yielding a total ignition of combination, which yielded lesser smoke releases (Yakup et al., 2003). The superior droplet of fuel velocity as well as lesser drop size attained as a result of superior fuel IP showed the way to improved global combination of fuel as well as air and abridged Ignition Delay (ID) (Lee et al., 2005).

Superior IP causes the diesel and biodiesel spray to vaporize rapidly that improves combustion rates yielding superior combustion temperatures. The earlier Start of Combustion (SOC) and superior heat release peak that yielded in higher in-cylinder temperature led to an amplified $\mathrm{NO}_{\mathrm{x}}$ emission (Charles et al., 2009). The BTE decreased with SOI later than $5^{\circ} \mathrm{bTDC}$ (Ye et al, 2011). The peak cylinder pressure of the biodiesel was a little inferior however the ignition delay ID was a little superior. Concerning emissions, the biodiesel had advantages to lower smoke, $\mathrm{CO}, \mathrm{HC}$ emissions chiefly by means of elevated fuel IP. The NOx emissions of the biodiesel was comparatively superior than the diesel (Hwang et al., 2014). Biodiesel blend (B20) exhibited superior engine performance from the perspective of Particulate Matter (PM) emission at every engine operating condition in contrast with diesel. This is attributable to lesser sulphur as well as aromatic component of biodiesel. Benzene Soluble Organic Fraction (BSOF) exhibited lessening tendency by way of growing engine operating load for both diesel as well as biodiesel. For B20, the BSOF component of PM was superior to that of diesel. The comparative inferior instability of the components of biodiesel may be the cause, signifying probable elevated contaminated prospective of biodiesel units (Jitendra et al., 2012). Works on diesel engine stimulated by means of coconut oil biodiesel and its mixtures through diesel has been reported in which it is reported that NOx emission amplified by means of an amplification in the proportion of the biodiesel in the mixture, whereas PM, $\mathrm{CO}, \mathrm{HC}$ diminished by means of an amplification of the proportion of biodiesel in the mixture (Nicholas et al., 2016).

India being a large sugarcane producing country, ethanol is obtainable in adequate amount and hence may be employed as automobile fuel. Use of ethanol in the diesel engines for transportation and power generation will help to boost rural economy and also reduces oil import cost. Ethanol is a promising alternative fuel as it can be created from commodities of agriculture for instance molasses, sugarcane, sugarbeet, corn, etc., through the process of fermentation of alcohol. Ethanol is a depleted priced oxygenate having elevated oxygen component of 34\% through weight. The employment of ethanol in diesel engines can give in to substantial lessening of particle emissions for motor vehicles. Employment of ethanol is preferred over methanol because methanol is a highly poisonous chemical produced synthetically. Also ethanol is chemically less toxic than methanol and it carries more energy per gallon. Methanol is more corrosive than ethanol. Even though Butanol has better properties compared to methanol, its manufacturing is more expensive and complex which adds to its initial cost which is not economical to consider it as a viable alternative. Hence ethanol is preferred over other alcohols.

Ethanol is an attractive oxygenate and is capable of being mixed together with diesel without the requirement of modifications to the engine (Prommeskwanchareon et al., 2007). Significant investigation on the possible use of ethanol-diesel fuel mixtures has been carried out by several investigators. It is reported that adding to the composition of ethanol in the mixture of fuel raises the brake specific fuel consumption as well as triggers a decline in brake thermal efficiency. Utilizing ethanol-diesel fuel mixtures in the diesel engine can yield noteworthy decline of nitrogen oxide, particulate matter and carbon monoxide emissions. But the foremost negative aspect of employing ethanol in diesel engine is that it has inadequate ability of ethanol being dissolved in diesel fuel which results in phase parting. Phase parting can be prohibited by using a co-solvent or an emulsifier that operates as a connection in molecular matching as well as union to create a homogenous mixture (Al-Hassan et al., 2012). Currently biodiesel is used as an additive or emulsifier for mixing of ethanol through regular diesel because of its possibility to enhance the ability of ethanol to dissolve in diesel fuel over an extensive variety of temperature and mixture properties. Fernando resolved the relative compatibility of ethanol, biodiesel and diesel. The results showed that the blends were stable and had equal and superior properties to regular diesel fuel (Fernando et al, 2004). Prommeskwanchareon have performed test of ability to dissolve on ethanol, biodieseldiesel blends using palm oil methyl ester as additive and gave an account of emission test outcomes of the fuel blends and discovered that $5 \%$ ethanol, $15 \%$ biodiesel and $80 \%$ diesel mixture was the mainly appropriate in view of its acceptable fuel properties and lower emissions (Prommeskwanchareon et al., 2007).

The objective of this investigation is to employ biodiesel (acid oil methyl ester) as an additive in making steady ethanol in diesel fuel mix as well as to carry out experiments on diesel engine performance with diesel-biodiesel-ethanol fuel mixes measured up to with that fuelled with pure diesel. This investigation largely direct attention to the influence of IT and IP on the combustion, performance and emission characteristics of CRDI engine when fuelled with diesel, ethanol and ester of non-edible oil i.e., AOME. CRDI engine performance were studied to optimize the fuel IT and IP for best BTE and then keeping optimum IT, IP for best BTE was found. Ultimately significant deductions were made from the experimental investigation on CRDI engine fuelled 
with diesel, ethanol and AOME respectively. In this work the biodiesel is produced by acid oil a waste by-product of vegetable oil refinery.Development of biodiesel from this resource offers multiple benefits like remedy of disposal problem encountered at refinery sites, value addition for the unwanted byproduct acid oil, considerable reduction in energy demands of vegetable oil refineries, increase in profitability of oil processing industry and offers enhanced remunerative prices for all variety of oil seeds and supports agriculture and generates greater employment potential.The fuels used in the study were renewable and helps in reducing the emissions which boons the contribution.

\section{Materials and Methods}

Acid oil for the present study was obtained from Chitradurga, sunflower private limited and Anjaneya Agro Tech private limited, a nearby vegetable oil refining units which produces around 350 metric tons of acid oil per year. Acid oil, a by-product of vegetable oil in refinery process is a feasible source since it is cheaply and effortlessly obtainable in noteworthy measures as unexploited by-product. Acid oil principally consist of extended-chain free fatty-acid combination in conjunction with miniature quantities of phospholipids and sterols (8-10\%), free moisture (5-8\%) and mineral acids (1-2\%) that reveal a characteristics strong odour as well as dark brown colour to the acid oil. Acid oil has fuel characteristics that are varied from those of diesel fuel due to its oxygenated kind and the sort of chain configuration. Heating values are somewhat lower whilst viscosity and ignition values are higher for this oil compared to diesel. Viscosity of acid oil needs to be reducedcloser to diesel and can be used as an alternative fuel. As the conventional trans-esterification process does not produce desired result in this direction a new method of "ED3R" esterification process was developed at the institute and was employed to produce the biodiesel from acid oil.In the method ED3R used ED refers to Extractive Distillation and 3R refers to Rectification, Refluxing and Reusing (Kulkarni et al, 2008). Since acid oil used to produce biodiesel contains about $75-80 \%$ free fatty acids the conventional transesterification process does not produce desired result. Hence above mentioned new method of "ED3R" esterification process was developed at the institute and was employed to produce the biodiesel. Using this method the esterification of acid oil to its methyl ester is almost complete and the yield obtained was about $85 \%$ which is impossible with other methods.

\subsection{Esterification of AOME}

In ED3R method adopted esterification is carried out employing "take-out" distillation principle. Surplus methanol employed is set right, re-changed and totally recycled in the procedure itself. Since esterification and recovery are distinct processes, they are implemented in separate entities, that is:

(i) Esterification unit (U-I): The entity responsible for esterification of acid oil in an anhydrous, irreversible manner as well as subjected to the occurrence of huge surplus methanol.

(ii) Recovery unit (U-II): The entity responsible for improvement, revival and recycle kind of processes for surplus methanol employed, performed concurrently at operations location.

The esterification unit (U-I) as well as the recovery unit (U-II) are interconnected and operated simultaneously in such a fashion that produced the needed effects. Two different kinds of processes, that is, production and separation of FAME compounds take place in the esterification location. Improvement, revival and recycle of surplus methanol employed were implemented in the revival entity. In U-I, esterification reaction occurs irreversibly to produce FAME and water first. Excess methanol present in the reaction mixture readily absorbs all the water produced and escapes out as methanol-water vapour mixture later as shown in the equation below.

$$
\begin{aligned}
& \mathrm{R}_{1} \mathrm{COOH}+(\mathrm{R}) \mathrm{CH}_{3} \mathrm{OH} \quad \stackrel{\text { Step } 1}{\underset{\mathrm{R}_{1} \mathrm{COOCH}_{3}+\mathrm{H}_{2} \mathrm{O}}{\longrightarrow}} \\
& \text { (Fatty acid)(Methanol)(FAME) (Water) } \\
& \mathrm{H}_{2} \mathrm{O}+\mathrm{x}\left(\mathrm{CH}_{3} \mathrm{OH}\right)_{(1)}\left(\mathrm{H}_{2} \mathrm{O} \times \mathrm{CH}_{3} \mathrm{OH}\right) \stackrel{\text { Step 2 }}{\longrightarrow} \\
& \text { (Water)(x Methanol) (Water - Methanol) v }
\end{aligned}
$$

Recovery of excess methanol used is first done by flash distillation and later by continuous distillation, which are carried out at recovery unit (U-II).

The esterification was made in a blocked kind of reactor supplied with modifiable component of electrical heating, an uninterrupted methanol movement as well as methanol vapour run off arrangements. Reaction combination was upheld at $70^{\circ} \mathrm{C}$, methanol-water fumes were compressed, reprocessed on the reverse all the way through the reaction's direction. Surplus methanol employed was gotten back and reemployed in succeeding lots. The resultant crude ester combination was rinsed three times by means of the same quantity of water as well as was permitted to remain during the night. Water stayed at the underneath was split. Pinnacle ester deposit manufactured was detached and lot refined. On the run vapours were packed together and gathered as tidy 
biodiesel. The reactor employed had a capability to deal with ten litters of acid oil per batch. About $75 \%$ to $80 \%$ yield was obtained as neat biodiesel.

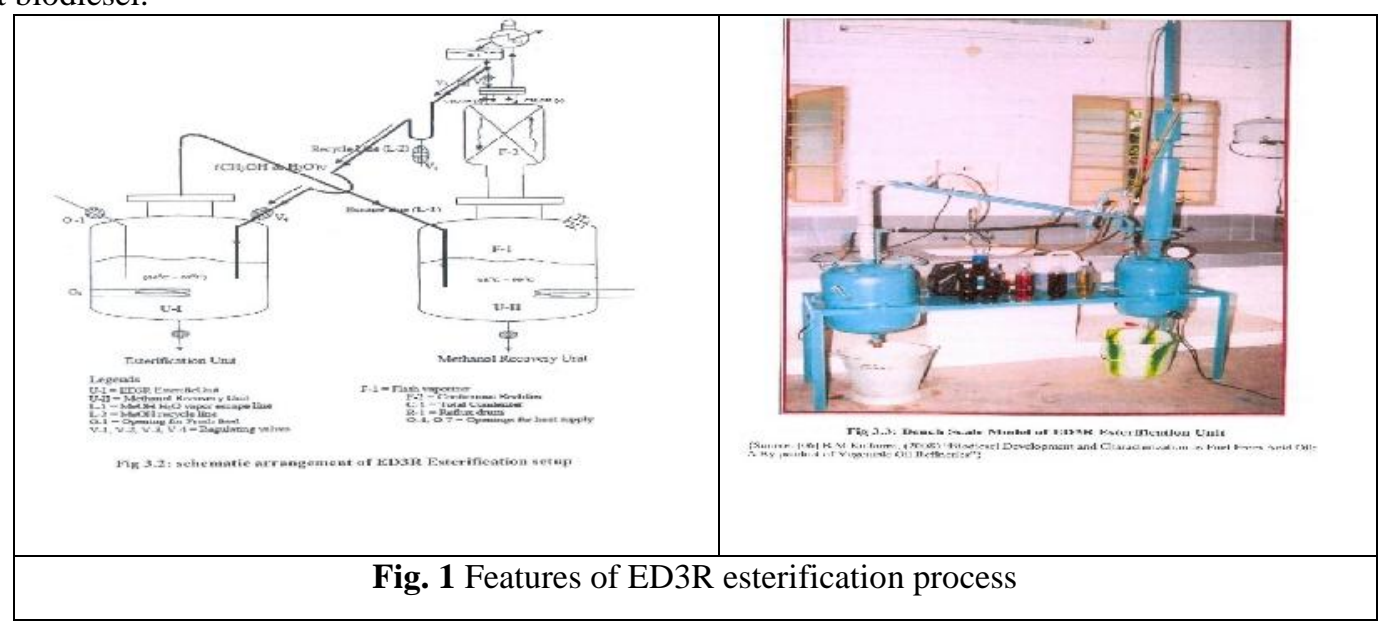

The employed diesel fuel for this investigation was acquired from a close Indian oil channel and its properties were examined to certify its agreement with standard specifications. The absolute ethanol of $99.5 \%$ pure was used for the study and was obtained from M/s Samson's distilleries Duggavati, Davanagere District Karnataka,India. Ethanol of $99.5 \%$ pure is only used because the inter-solubility of three fuels used was not limited and they could be mixed into a homogenous solution at any ratio used. The diesel, biodiesel (AOME) and ethanol were mixed into a homogenous mixture by a magnetic stirrer and blends with(\%v/v) 5,10,15 of ethanol 70,80,90 of biodiesel and 5,10,15 of diesel were prepared.

As ethanol, biodiesel and diesel blends are prepared using $99.5 \%$ pure ethanol the stability was checked by storing these blends for a period of three months. Phase separation was not observed even after 60 days (when stored in atmospheric conditions) as ethanol content used by volume is less when compared to volume of biodiesel and diesel. The properties of acid oil and base fuels and their blends were found out as per ASTM standards and are shown as below. Table 1 shows the fuel properties of Acid oil. Table 2 shows the properties of base fuels like ethanol, AOME and diesel respectively. Table 3 shows the properties of AOME and its blends with diesel and alcohol used in the study.

Table 1Fuel properties of Acid oil

\begin{tabular}{|c|l|l|}
\hline Sl. No. & \multicolumn{1}{|c|}{ Property } & Value \\
\hline 1. & Specific gravity & 0.914 \\
\hline 2. & Kinematic viscosity $(\mathrm{cSt})$ & 48.4 \\
\hline 3. & Heating value $(\mathrm{MJ} / \mathrm{kg})$ & 36.6 \\
\hline 4. & Flash point $\left({ }^{\circ} \mathrm{C}\right)$ & 212 \\
\hline 5. & Pour point $\left({ }^{\circ} \mathrm{C}\right)$ & +11 \\
\hline 6. & Cetane number & 39.5 \\
\hline 7. & Acid value $(\mathrm{mgKOH} / \mathrm{gr})$ & 198 \\
\hline 8. & Iodine value & 122 \\
\hline
\end{tabular}

Table 2Properties of base fuels

\begin{tabular}{|l|c|c|c|}
\hline \multicolumn{1}{|c|}{ Property } & Ethanol & $\begin{array}{c}\text { Acid oil methyl ester } \\
\text { Biodiesel }\end{array}$ & Diesel \\
\hline Density $\left(\mathrm{kg} / \mathrm{m}^{3}\right)$ & 789 & 885 & 819 \\
\hline Kinematic viscosity $(\mathrm{cSt})$ & 1.21 & 5.8 & 2.94 \\
\hline Flash point $\left({ }^{\circ} \mathrm{C}\right)$ & 14 & 97 & 57 \\
\hline Fire point $\left({ }^{\circ} \mathrm{C}\right)$ & 18 & 113 & 64 \\
\hline Calorific value $(\mathrm{kJ} / \mathrm{kg})$ & 26843 & 41577 & 44189 \\
\hline Cloud point $\left({ }^{\circ} \mathrm{C}\right)$ & -7 & 8 & 2 \\
\hline Pour point $\left({ }^{\circ} \mathrm{C}\right)$ & $\leq-35$ & 2 & -16 \\
\hline Cetane number & 8 & 57 & 52 \\
\hline Carbon residue \% & - & 1.96 & 0.5 \\
\hline Acid value $(\mathrm{mgKOH} / \mathrm{gr})$ & - & 0.68 & - \\
\hline
\end{tabular}


Table 3 Properties of blends

\begin{tabular}{|c|c|c|c|c|}
\hline Blends $\longrightarrow$ & $\begin{array}{l}E: B: D \\
15: 70: 15\end{array}$ & $\begin{array}{l}E: B \quad: D \\
10: 80: 10\end{array}$ & $\begin{array}{c}\mathrm{E}: \mathrm{B}: \mathrm{D} \\
05 \cdot 90 \cdot 05\end{array}$ & $\begin{array}{c}\mathrm{E}: \mathrm{B}: \mathrm{D} \\
10 \cdot 90 \cdot 00\end{array}$ \\
\hline Properties & & & & \\
\hline Density $\left(\mathrm{kg} / \mathrm{m}^{3}\right)$ & 841 & 848 & 861 & 856 \\
\hline Kinematic viscosity $(\mathrm{cSt})$ & 3.6 & 4.3 & 5.1 & 4.95 \\
\hline Flash point $\left({ }^{\circ} \mathrm{C}\right)$ & 16 & 26 & 48 & 42 \\
\hline Fire point $\left({ }^{\circ} \mathrm{C}\right)$ & 21 & 34 & 54 & 49 \\
\hline Calorificvalue $(\mathrm{kJ} / \mathrm{kg})$ & 36777 & 38338 & 39942 & 38572 \\
\hline Cloud point $\left({ }^{\circ} \mathrm{C}\right)$ & 3 & 4 & 4 & 2 \\
\hline Pour point $\left({ }^{\circ} \mathrm{C}\right)$ & -6 & -4 & -3 & -3 \\
\hline Cetane number & 48.58 & 50.8 & 54 & 49.26 \\
\hline Carbon residue \% & 0.19 & 0.28 & 0.41 & 0.37 \\
\hline Copperstrip corrosion test & Not worse than 1 & Not worse than 1 & Not worse than 1a & Not worse than 1 \\
\hline
\end{tabular}

\subsection{Experimental methodology}

An initial conduct of experiments was made on the modified CRDI engine energized through AOME as well as its mixtures with diesel as well as ethanol to study the effect of injection timing (IT), in which IT was varied from $25^{\circ}$ before top dead centre (bTDC) to $5^{\circ}$ after top dead centre (aTDC) keeping injector pressure (IP) of 600 bar, compression ratio (CR) of 17.5 and engine speed of $1500 \mathrm{rpm}$ for 80 and 100\% loading conditions respectively. A DELTA 1600 S Exhaust Gas Analyzer shown was employed in measuring the exhaust discharges like $\mathrm{CO}, \mathrm{HC}, \mathrm{CO}_{2}$, and $\mathrm{NOx}$ correspondingly. Smoke discharges were measured with Hartridge Smoke meter. Tables 4 and 5 show the specifications of the Exhaust Gas Analyzer and Hartridge Smoke meter respectively. Further experiments were conducted on the CRDI engine fuelled with AOME and its blends with diesel and ethanol, to optimize the injector opening pressure (IP) in which IPs were varied from 600 bar to 1000 bar keeping an optimized IT of $10^{\circ} \mathrm{bTDC}$.

Table 4 Specifications of Exhaust Gas Analyzer

\begin{tabular}{|c|c|}
\hline Type & DELTA $1600 \mathrm{~S}$ \\
\hline Object of Measurement & $\begin{array}{l}\text { Carbon monoxide }(\mathrm{CO}) \text {, Carbon Dioxide }\left(\mathrm{CO}_{2}\right) \\
\text { and Hydrocarbons }(\mathrm{HC})\end{array}$ \\
\hline Range of Measurement & $\begin{array}{l}\mathrm{HC}=0 \text { to } 20,000 \mathrm{ppm} \text { as } \mathrm{C}_{3} \mathrm{H}_{8} \text { (Propane) } \\
\mathrm{CO}=0 \text { to } 10 \% \\
\mathrm{CO}_{2}=0 \text { to } 16 \% \\
\mathrm{O}_{2}=0 \text { to } 21 \% \\
\mathrm{NO}_{\mathrm{X}}=0 \text { to } 5000 \mathrm{ppm} \text { (as Nitric Oxide) }\end{array}$ \\
\hline Accuracy & $\begin{array}{l}\mathrm{HC}=+/-30 \mathrm{ppm} \mathrm{HC} \\
\mathrm{CO}=+/-0.2 \% \mathrm{CO} \\
\mathrm{CO}_{2}=+/-1 \% \mathrm{CO}_{2} \\
\mathrm{O}_{2}=+/-0.2 \% \mathrm{O}_{2} \\
\mathrm{NO}_{\mathrm{X}}=+/-10 \mathrm{ppm} \mathrm{NO}\end{array}$ \\
\hline Resolution & $\begin{array}{l}\mathrm{HC}=1 \mathrm{ppm} \\
\mathrm{CO}=0.01 \% \text { Vol. } \\
\mathrm{CO}_{2}=0.1 \% \text { Vol. } \\
\mathrm{O}_{2}=0.01 \% \text { Vol. } \\
\mathrm{NO}_{\mathrm{X}}=1 \mathrm{ppm}\end{array}$ \\
\hline Warm up time & 10 min. (self-controlled) at $20^{\circ} \mathrm{C}$ \\
\hline Speed of Response Time & Within $15 \mathrm{sec}$. for $90 \%$ response \\
\hline Sampling & Directly sampled from tail pipe \\
\hline Power Source & 100 to $240 \mathrm{~V} \mathrm{AC} / 50 \mathrm{~Hz}$ \\
\hline Weight & $800 \mathrm{~g}$ \\
\hline Size & $100 \mathrm{~mm} \times 210 \mathrm{~mm} \times 50 \mathrm{~mm}$ \\
\hline
\end{tabular}

Table 5 Specifications of Smoke Meter

\begin{tabular}{|l|l|}
\hline \multicolumn{1}{|c|}{ Type } & \multicolumn{1}{c|}{ Hartridge Smokemeter } \\
\hline Object of Measurement & Smoke \\
\hline Measuring range opacity & $0-100 \%$ \\
\hline Accuracy & $+/-2 \%$ relative \\
\hline
\end{tabular}


Table 5 (cont'd) Specifications of Smoke Meter

\begin{tabular}{|l|l|}
\hline \multicolumn{1}{|c|}{ Type } & \multicolumn{1}{c|}{ Hartridge Smokemeter } \\
\hline Resolution & $0.1 \%$ \\
\hline Smoke length & $0.43 \mathrm{~m}$ \\
\hline Ambient Temperature Range & $-5^{0} \mathrm{C}$ to $+45^{0} \mathrm{C}$ \\
\hline Warm up time & $10 \mathrm{~min}$. (self-controlled) at $20^{\circ} \mathrm{C}$ \\
\hline Speed of Response Time & Within 15 sec. for $90 \%$ response \\
\hline Sampling & Directly sampled from tail pipe \\
\hline Power Supply & 100 to $240 \mathrm{~V}$ AC $/ 50 \mathrm{~Hz}$ \\
$10-16 \mathrm{~V}$ DC @ $15 \mathrm{amps}$
\end{tabular}

\section{Engine setup}

Figure 2 shows the schematic diagram of the CRDI experimental test rig. Specifications of engine used for the study are shown in Table 6. Table 7 shows the specifications of CRDI injector used for the study.

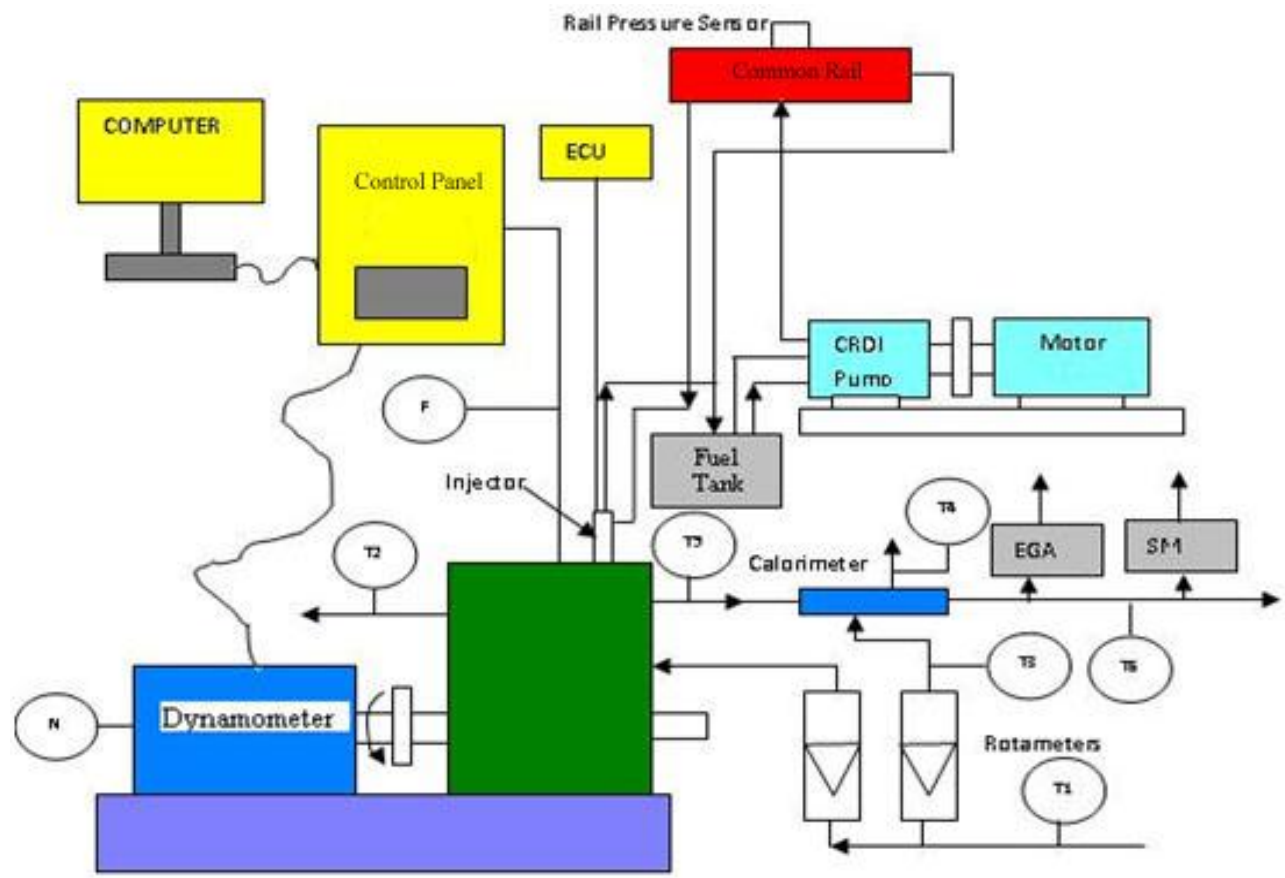

T1, T3 - Inlet Water Temperature, T2 - Outlet Engine Jacket Water Temperature T4 - Utlet Calorimeter Water Temperature, T5 - Exhaust Gas Temperature before Calorimeter T6 - Exhaust Gas Temperature after Calorimeter, F - Fluid Flow differential pressure Unit $\mathrm{N}$ - Speed Encoder, EGA - Exhaust Gas Analyser, SM - Smoke Meter

Fig. 2 Schematic diagram of the CRDI experimental test rig

Table 6 Specifications of CI engine

\begin{tabular}{|c|l|l|}
\hline Sl. No. & \multicolumn{1}{|c|}{ Parameter } & \multicolumn{1}{c|}{ Specifications } \\
\hline 1 & Type & TV1 ( Kirlosker make) \\
\hline 2 & Software used & Engine soft \\
\hline 3 & Nozzle opening pressure & 200 to 225 bar \\
\hline 4 & Static injection timing & $23^{\circ}$ bTDC \\
\hline 5 & Governor type & Mechanical centrifugal type \\
\hline 6 & No of cylinders & Single cylinder \\
\hline 7 & No of strokes & Four stroke \\
\hline 8 & Fuel & H. S. Diesel \\
\hline 9 & Rated power & $3.7 \mathrm{~kW}$ (5 HP) @ 1500 RPM \\
\hline
\end{tabular}


Table 6 (cont'd) Specifications of CI engine

\begin{tabular}{|c|l|l|}
\hline Sl. No. & \multicolumn{1}{|c|}{ Parameter } & \multicolumn{1}{c|}{ Specifications } \\
\hline 10 & Maximum torque and Engine speed & $1500 \mathrm{rpm}$ \\
\hline 11 & Cylinder diameter (Bore) & $0.0875 \mathrm{mtr}$ \\
\hline 11 & Stroke length & $0.11 \mathrm{~m}$ \\
\hline 12 & Compression ratio & $17.5: 1$ \\
\hline
\end{tabular}

Table 7 Injector Specification

\begin{tabular}{|l|l|}
\hline No of holes & 6 \\
\hline Diameter of the nozzle & $0.18 \mathrm{~mm}$ \\
\hline Angle of injector hole & Parallel to head \\
\hline Injection pressure & $1000 \mathrm{bar}$ \\
\hline
\end{tabular}

\section{Results and Discussion}

Experiments were conducted on the CRDI engine fuelled with AOME and its blends with diesel to study its performance highlighting the effect of IT and IOP. The experiments were conducted for higher engine loads of 80 and 100\% and at the rated speed of $1500 \mathrm{rpm}$ keeping rail pressure of 600 bar by adjusting the pump flow and the pressure regulator valve to optimize the IT. The rail pressure was then varied from 600 to 1000 bar keeping the optimized IT constant. The IT is varied from $25^{\circ} \mathrm{bTDC}$ to $5^{\circ}$ aTDC in steps of $5^{\circ} \mathrm{CA}$. Beyond $5^{\circ}$ aTDCconsiderable knocking was observed. It may be noted that the injector employed was well suited with the engine and the results represent the variation of parameters and demonstrate the capability of the system.

\subsection{Effect of Injection timing}

\subsubsection{Effect of injection timing on BTE}

Figure 3 shows the effect of IT on BTE of CRDI engine fuelled with different blends of AOME, diesel and Ethanol for $80 \%$ and $100 \%$ loads respectively. AOME and its blends with ethanol and diesel showed poor performance compared to diesel. This may be attributed to its lower calorific value, lower volatility and higher viscosity of blended fuel combinations. The addition of ethanol and diesel to AOME increases the BTE. The presence of oxygen in the ethanol and higher calorific value of diesel in the blends further helps in achieving complete combustion of the fuel combinations used. The BTE increases slightly with increase in concentration of ethanol and diesel. As AOME has the ability to reduce the interfacial tension between two or more interacting immiscible liquids, as the percentage of ethanol in the mixture with diesel is increased, improvement in the brake thermal efficiency can be observed.Higher latent heatand lower flame temperature of ethanol in the blend limits heat losses from the cylinder which improves combustion and further enhances BTE. Figure also shows effect of IT on BTE of CRDI enginefuelled with diesel, biodiesel and ethanol for different ITs for $80 \%$ and $100 \%$ loads. The maximum BTE occurred for IT between $10^{\circ}$ to $5^{\circ} \mathrm{bTDC}$ for both higher loads at constant IP of 600 bar for the fuel combinations used. Advancement or retardation from the optimum value of IT deteriorated BTE as shown and the similar results were reported in the literature (Monyem A et al, 2001, Senatore A et al, 2008, Peng Ye et al, 2011). From the figure, it is observed that higher BTE occurs at SOI between $10^{\circ}$ and $5^{\circ}$ bTDC and the BTE decreases with SOI later then $5^{\circ} \mathrm{bTDC}$. Engine operation with AOME and its blends with diesel and ethanol performed better at $10^{\circ} \mathrm{IT}$ than other ITs tested. However performance of biodiesel and its blends with diesel and ethanol was poor compared to its counterpart diesel due to their higher viscosity and lower calorific value.

\subsubsection{Effect of injection timing on emission characteristics}

\section{Smoke Emissions}

Figure 4 shows the effect of IT on smoke opacity for CRDI system operation withAOME, different blends of AOME, Diesel and Ethanol at $80 \%$ and $100 \%$ loads. Smoke emission is found to be higher with AOME and their blends for higher loads compared to diesel. Poor evaporation rate of blended fuels due to their high latent heat of evaporation of ethanol is responsible for the observed trends. At higher loads, the flame temperature is high, which results in low smoke emission with AOME and its blends than AOME. As the concentration of ethanol and diesel is increased in AOME the smoke emission is reduced at higher loads which may be due to overall leaning operation of the engine as the combustion is assisted by the presence of fuel bound oxygen of ethanol. Also high volatility of ethanol has a remarkable effects on the reduction of smoke at high engine loads. Results shows that smoke emission of blends was higher than that of neat diesel under the same operating conditions. This can be attributed to the presence of free fatty acids (FFA) in the biodiesel leading to poor air fuel mixture.At an IP of 600 bar the smoke emissions of all injected fuels decrease with retarded IT up to $10^{\circ} \mathrm{bTDC}$ and was minimum at that IT. This could be due to better combustion on account of more available time for oxidation. Smoke emission of all the fuels increased when IT is retarded due to diffusion combustion phase caused by reduced rate of fuel-air mixing due to later injection (Savin et al., 2009). It is observed that smoke emissions of blends decreases with increase in percentage of diesel and ethanol in the blends which may be attributed to increased volatility and better mixing of air-fuel mixture. 

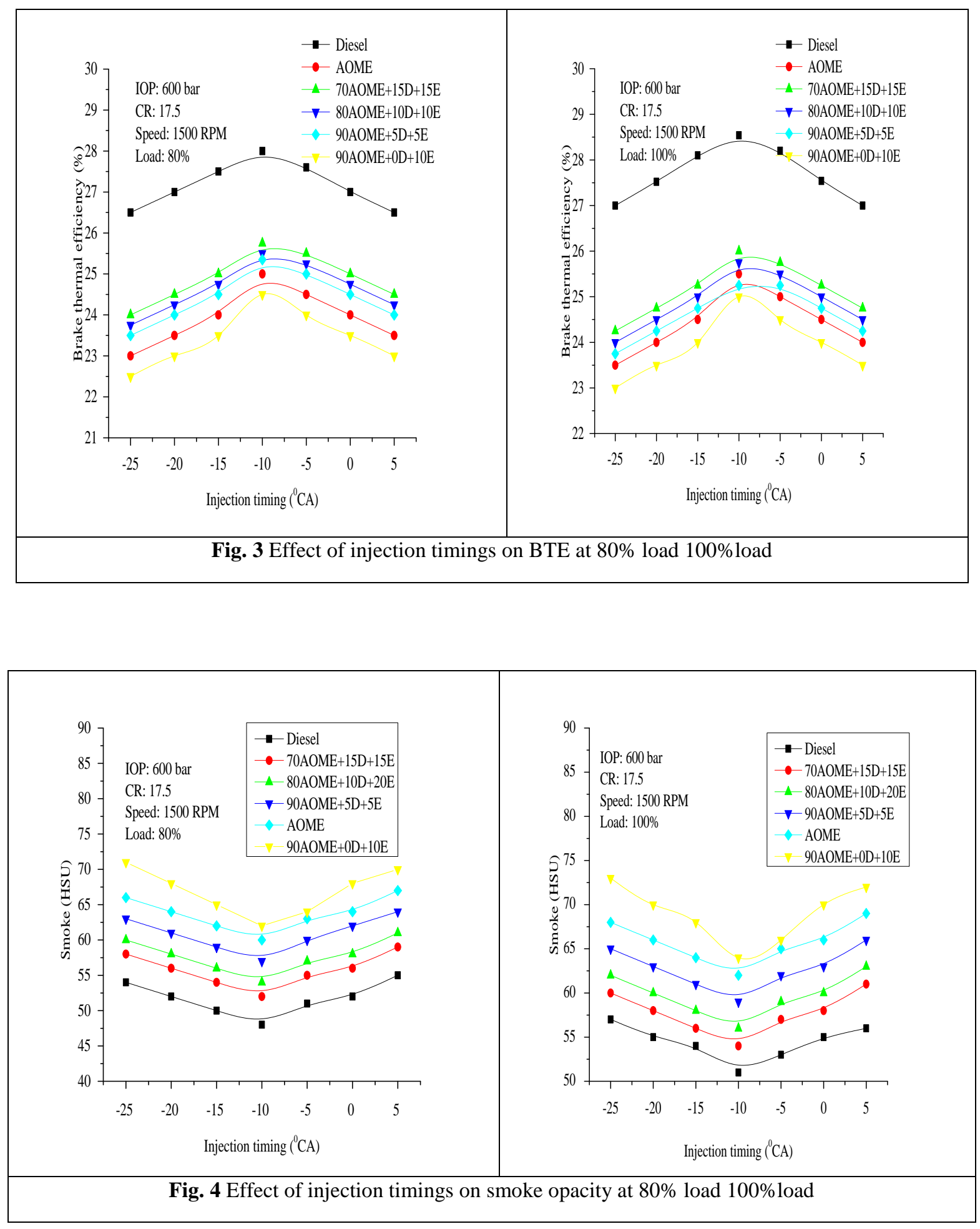

\section{HC Emissions}

Figure 5 shows the effect of IT on HC emissions for CRDI engine fuelled with AOME, and its blends of AOME, diesel and Ethanol at $80 \%$ and $100 \%$ loads. $\mathrm{HC}$ emissions increased for AOME and its blends compared to diesel due to their low cetane number of blends, higher fuel consumption and higher latent heat of vaporization which lowers the cylinder temperature. AOME and their blends with diesel and ethanol have higher viscosity which results in poor atomization compared to diesel at the same injection pressure and the associated lower brake thermal efficiency of the blends obtained compared to diesel. Results showed that $\mathrm{HC}$ emissions of blends increases with decrease in percentage of diesel and ethanol in blends. Also associated wall wetting observed with AOME and their blends could also be responsible for the observed trends. HC emissions showed decreasing trend up to IT $10^{\circ} \mathrm{bTDC}$ where fuel BTE was found to be higher (Carlo $\mathrm{N}$ et al, 2002) and showed increasing trend as IT was retarded. 


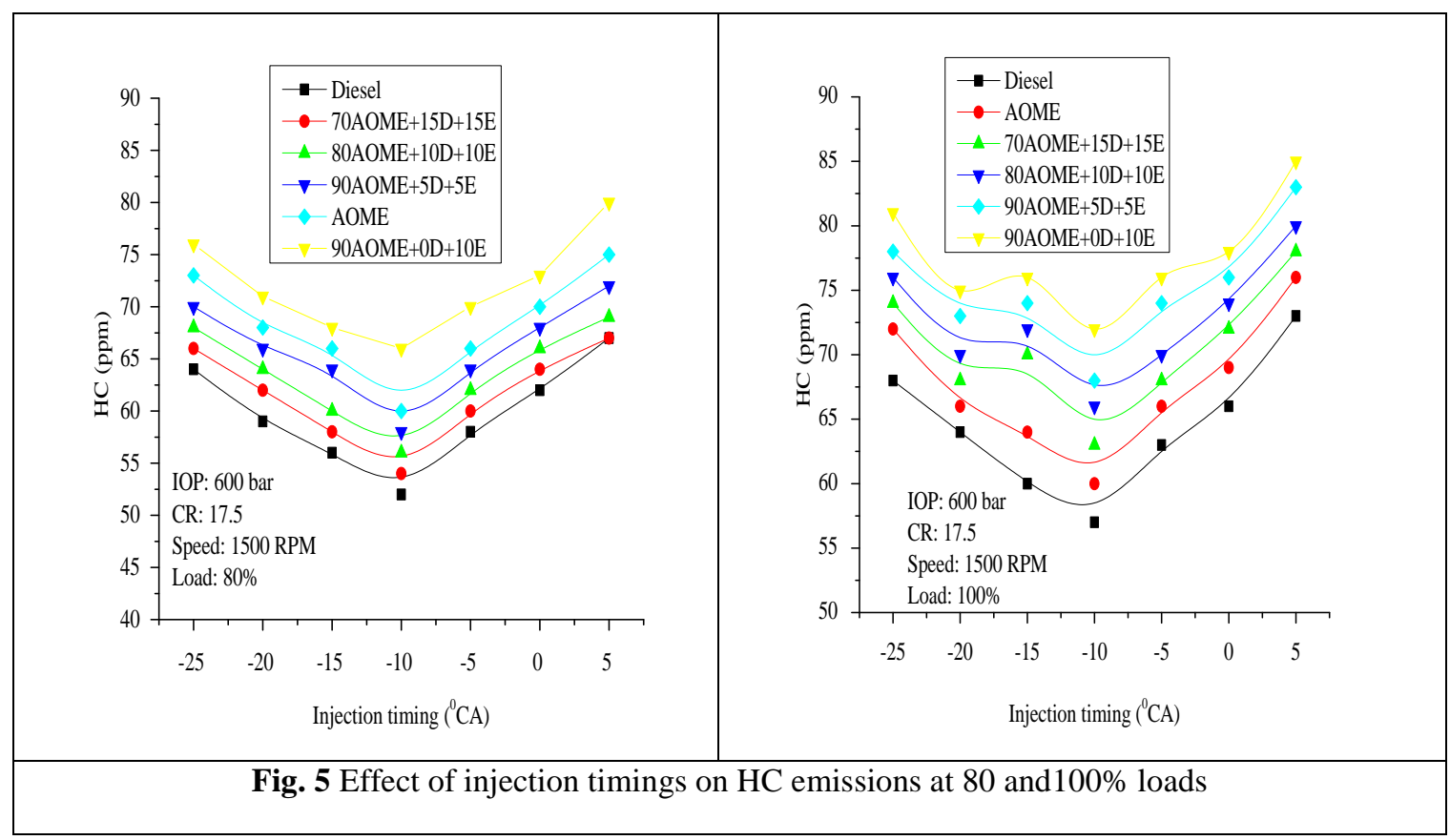

\section{CO Emissions}

Figure 6 shows the effect of IT on CO emissions for CRDI engine fuelled with AOME and its blends with Diesel and Ethanol at $80 \%$ and $100 \%$ loads. CO emissions are higher for AOME and their blends due to their lower cetane number, higher latent heat of evaporation compared to diesel. Reduced vaporization results in lesser time available for the fuel to burn completely that results in considerable increase in $\mathrm{CO}$ emissions. For blends at higher load enough time is available for combustion to occur with better mixing and inbuilt fuel oxygen that results in complete combustion and hence slightly reduced the $\mathrm{CO}$ emissions occur. Results shows that $\mathrm{CO}$ emissions of blends decrease with increase in ethanol and diesel percentage compared to AOME. CO emissions showed decreasing trend up to $10^{\circ} \mathrm{bTDC}$ and showed increasing trend as IT was retarded. This could be due to decreased BTE which increases the fuel delivered. At retarded IT the initial pressure and temperature of air is higher with higher oxygen content of AOME increases the oxidation process between carbon and oxygen molecules.

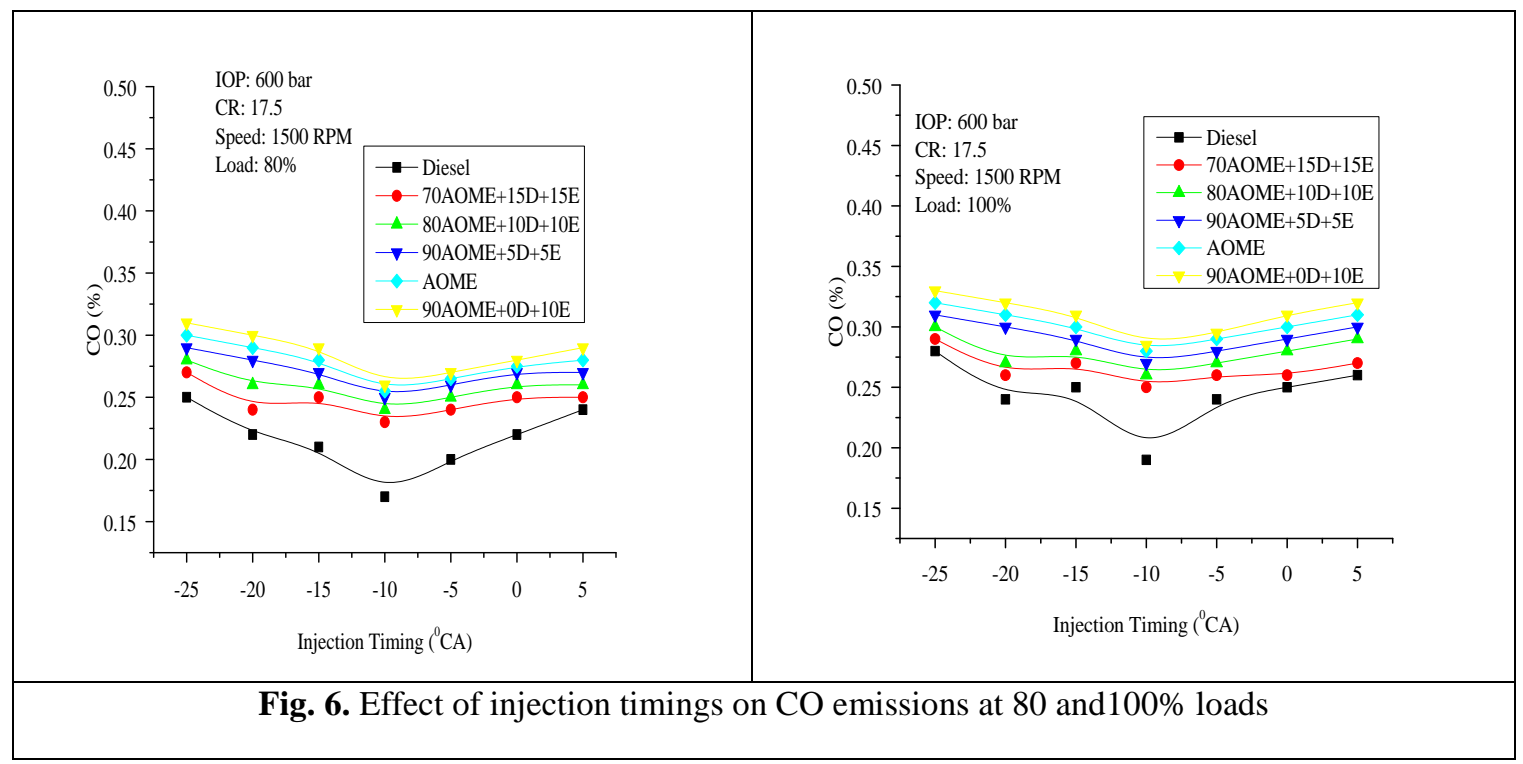

\section{NOx Emissions}

Figure 7 shows the variations of NOx emissions with higher engine loads for AOME and its blends with diesel and AOME. The rate of NOx formation is primarily a function of flame temperature, the residence time available at that temperature, and the availability of oxygen in the combustion chamber. At higher engine load due to increased quantity of fuel that is injected and combusted in the cylinder causes higher gas temperature and results in more NOx formation in the engine cylinder.NOx emission slightly reduced with AOME and their blends ethanol and diesel compared to diesel. As ethanol in the blendsincreases combustion 
temperature becomes lower due to low calorific value and the higher latent heat of vaporization of ethanol. This results in reduced flametemperature and hence lower NOx emissions occur as less heat energy is released after combustion. Fig also shows effect of IT on NOx emissions of different blends of AOME, Diesel and Ethanol and diesel at $80 \%$ and $100 \%$ loads. NOx emissions of AOME and its blends are comparatively lesser than diesel as they provide lower in-cylinder peak temperature. NOx emissions were higher for advanced IT for both AOME and its blends and Diesel as it increases peak cylinder pressure due to longer ID resulting in higher peak cylinder temperature (Leung D et al, 2006). NOx emission is lower for the blends with lower percentage of diesel and ethanol which may be due to their lower cetane number, lower peak pressure and temperature when compared to diesel operation.

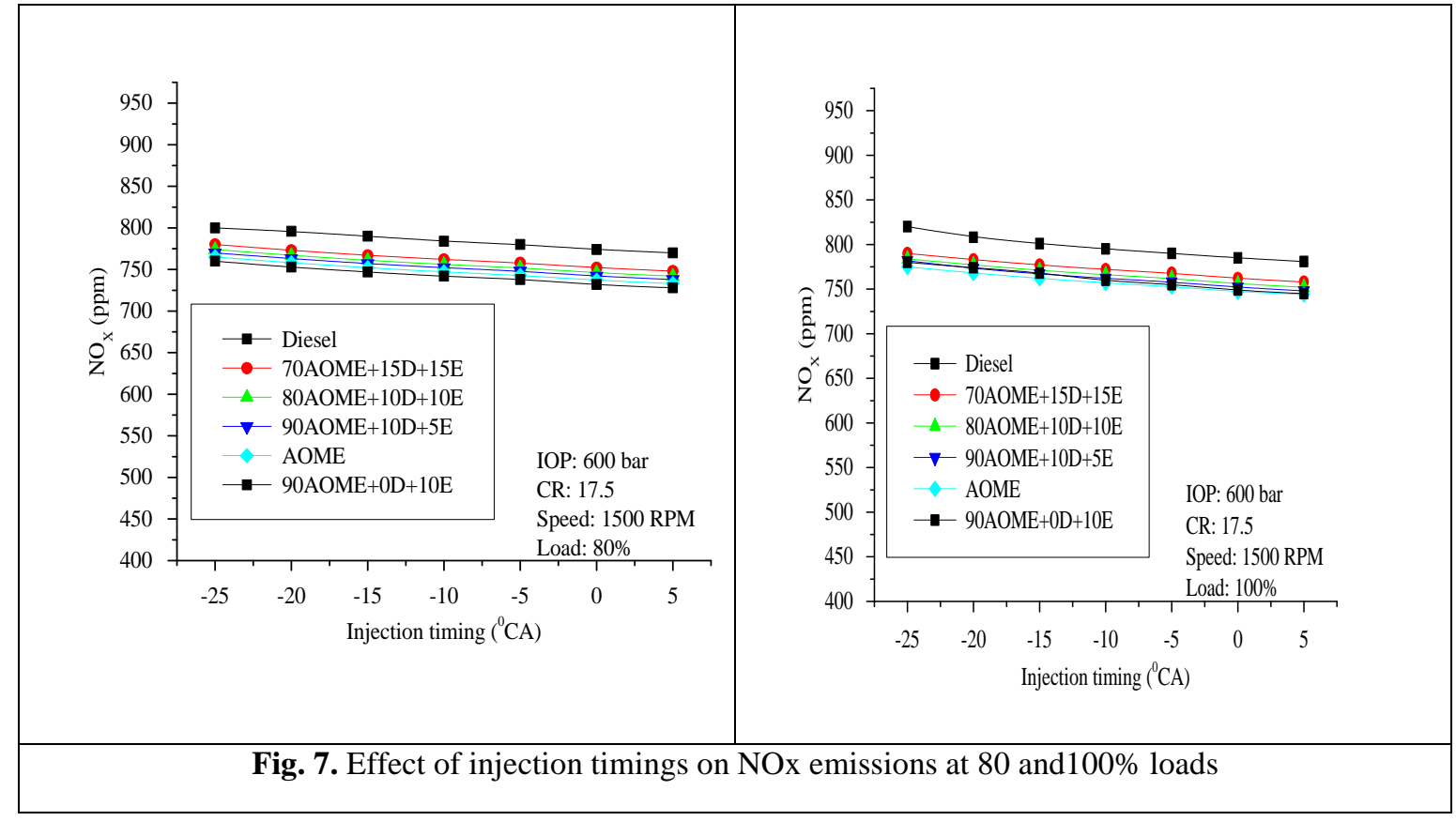

\subsection{Effect of Injection Pressure}

In the second phase experiments were conducted to study the influence of IP on CRDI engine fuelled with AOME and its blends with diesel and alcohol. Keeping optimized IT of $10^{\circ} \mathrm{BTDC}$ constant IOP was varied from 600 bar to 1000 bar with constant engine speed at $1500 \mathrm{rpm}$.

4.2.1 Brake Thermal Efficiency

Figure 8 shows the effect of IOP on BTE of the engine when fuelled with AOME, and its blends with diesel and Ethanol for varied IP at $80 \%$ and 100\% load respectively. Lower BTE were found for AOME and its blends compared to diesel operation for all IPs tested. Lower CN, higher viscosity and lower volatility associated with AOME and their blends led to poor atomization and slightly inhomogeneous mixture during the ID period which delays the start of combustion process. At $100 \%$ load similar trends were observed with reduced BTE as shown in figure. Addition of diesel and ethanol in the AOME increase blends volatility and decrease viscosity which facilitate enhanced brake thermal efficiency. Further performance of AOME and its blends with diesel and ethanol was poorer with decrease in percentage of diesel and ethanol in AOME. This could be attributed to higher viscosity and lower volatility of biodiesel blended fuels. As the IP was increased from 600 to 900 the BTE increased and highest BTE was observed with 900 bar (Pundir et al., 2007, Bakar et al., 2008). At 100\% load similar trends were observed with lower BTE values as shown in the Fig. Beyond 900 bar IOP there was no significant improvement in BTE. This is probably due to higher IP led to wall wetting. Too high IP (1000bar) led to a delayed injection negating the gain in the performance of CRDI engine.

\subsubsection{Exhaust emissions}

This section explains the effect of IP on the emission characteristics such as smoke, HC, CO and NOx of the diesel engine fuelled with selected fuel combinations.

\section{Smoke emissions}

The effect of IP on smoke emission of CRDI engine fuelled with AOME and its blends with diesel and ethanol at $80 \%$ and $100 \%$ load respectively is shown in Figure 9. AOME and their blends showed higher smoke opacity due to their higher viscosity compared to diesel operation. AOME and their blends have heavier molecular structure due to their higher viscosity that resulted into larger fuel droplet size for the same IOP compared to diesel. The improper air-fuel mixture achieved in CC resulted into higher smoke emissions compared to neat diesel operation. Increasing IOP from 600 to 900 bar results in smoke reduction and beyond 1000 bar this effect is not pronounced due to injection system limitation. Lowest smoke levels were observed at the IP of 
900 bar. Addition of ethanol and diesel in AOME further improves volatility and coupled with increased IOP enhances the atomization which improves fuel air mixing inside the CC resulting in reduced smoke emission (Yakup et al., 2003). Hence with increased ethanol concentration in the blends volatility increases and increased IOP enhances atomization and improves spray characteristics of the injected fuels which reduces smoke emission.
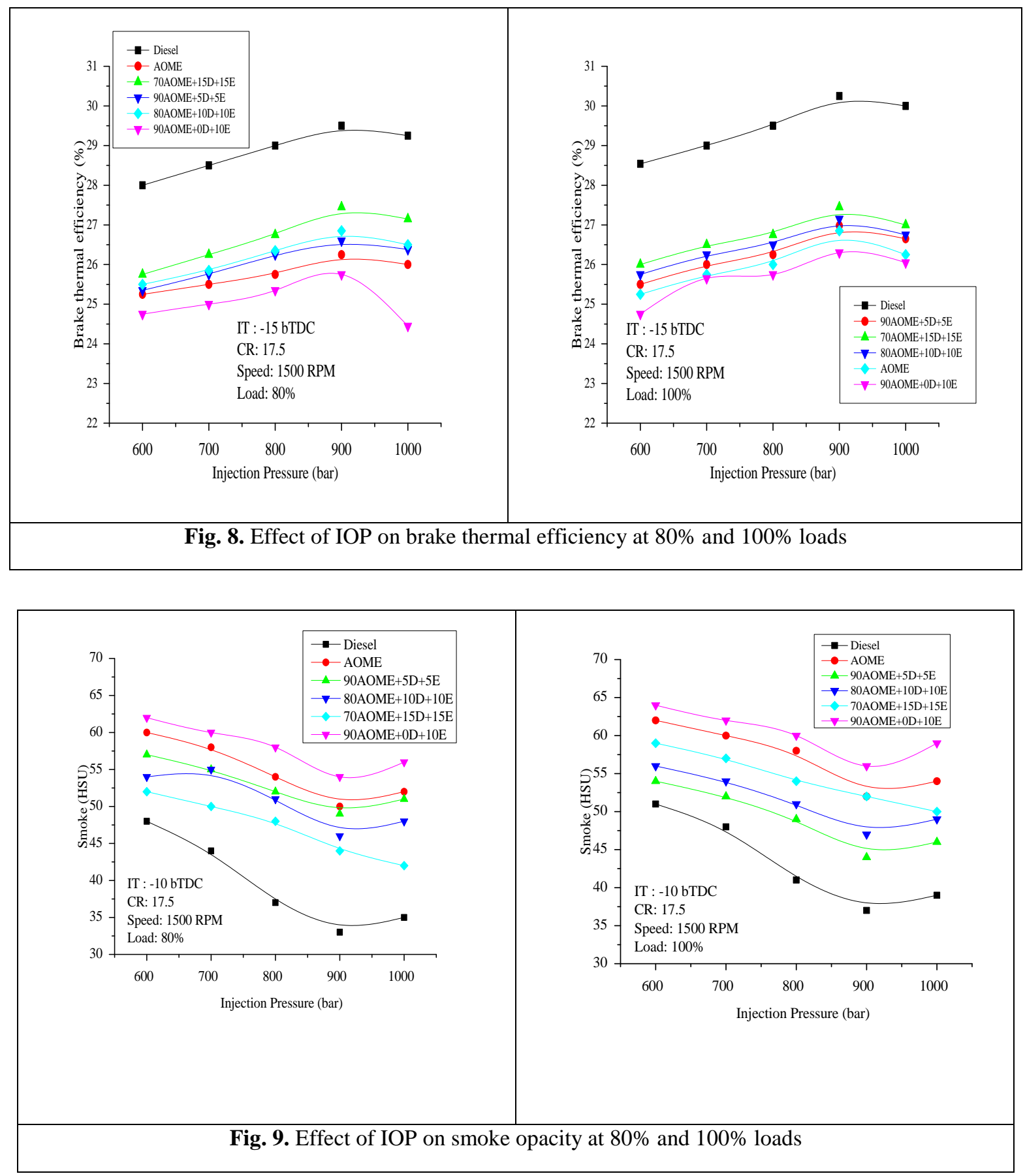

\section{HC and CO Emissions}

Figures10 and 11 shows the effect of IOP on $\mathrm{HC}$ and $\mathrm{CO}$ emissions for AOME, and its blends with diesel and Ethanol at 80\% and 100\% load. AOME, and their blends with ethanol and diesel showed higher $\mathrm{HC}$ and $\mathrm{CO}$ emissions due to their higher viscosity and lower volatility. Ethanol addition in AOME results in better air-fuel mixing and improves volatility of the blends and hence the $\mathrm{HC}$ and $\mathrm{CO}$ emissions showed decreasing trends. With increase in Diesel and Ethanol content in the blends $\mathrm{HC}$ and CO emissions decreased which may be due to higher oxygen content, but were comparatively higher than diesel fuel as BTE was lower for AOME engine operation. Increased IOP of the blends resulted in enhanced atomization followed by improved combustion of the fuel mixture combinations used. At highest IP of 1000 bar increase in HC emission is observed which may be 
due to the injection pressure limitation of the system. Also a higher IP led to a considerable portion of the combustion of mixture to occur in the diffusion phase on account of the smaller ID.

Mixed results on CO, HC NOx emissions for ethanol-biodiesel-diesel blends in diesel engines have been reported in the literature. A number of reports demonstrate no major modification in $\mathrm{CO}$ emissions, while a few studies confirm a rise or decline in $\mathrm{CO}$ emissions. In most of the such works undertaken small amount of ethanol in ethanol-biodiesel-diesel blends have been reported and maximum amount of biodiesel used in these blends was restricted to about $45 \%$. However, the aim of the present work is to replace diesel with maximum fraction of biodiesel and ethanol and hence the blends are prepared in order to have higher oxygen content keeping the important properties within acceptable limits. The results obtained are comparable with the previous works carried out with less than $50 \%$ biodiesel and hence it can be concluded that the existing diesel engine can be used with higher percentage of biodiesel with suitable engine parameter modifications.
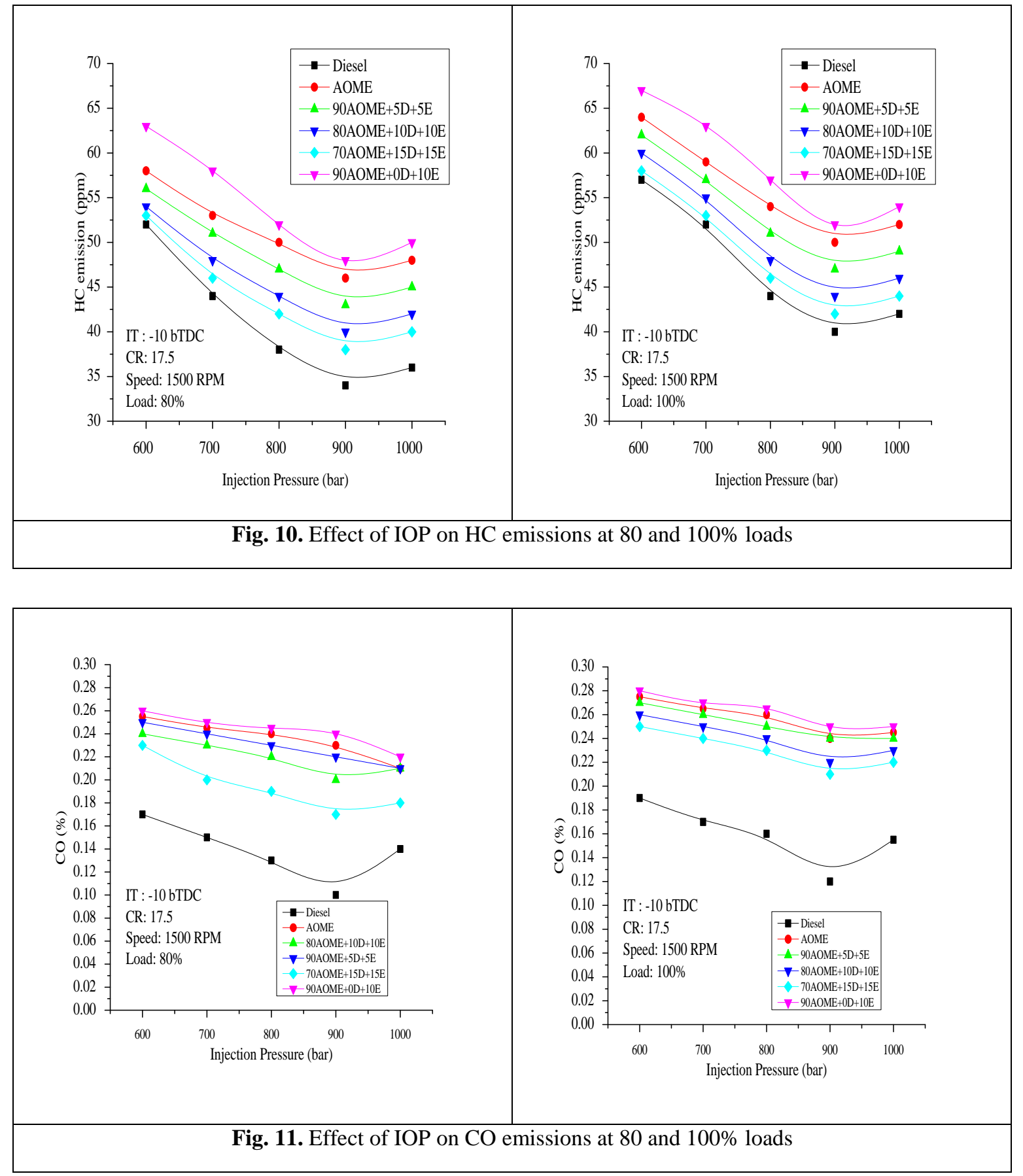

\section{NOx emissions}

Figure 12 shows effect of IOP on NOx emissions of different AOME and its blends withdiesel and ethanol at 80\% and 100\% load. NOx is formed due to oxidation of nitrogen present in the air during burning of air-fuel mixture in the combustion chamber. 
Its formation is dependent on the flame temperature existing in the combustion chamber. Mixed results on NOx emissions for ethanol-biodiesel-diesel blends in diesel engines have been reported in the literature. Similar to $\mathrm{HC}$ and CO emissions contradictory results were reported regarding NOx emissions for such fuel blends engine operation. Some research showed an increase in NOx emissions while some investigations showed reduction in NOx emissions. AOME and their blends with ethanol and diesel showed lower NOx emissions compared to diesel operation due to more heat released during diffusion combustion phase and could be attributed to superior oxidation and short premixed combustion observed for such blend operation. It may however be noted that addition of ethanol in AOME blends enhances the combustion process and increase in ethanol content in the blend increases the fuel droplet velocity by decreasing the droplet size and this coupled with increased IOP leads to better overall mixing of fuel and air leading to higher in-cylinder temperature (Muller et al, 2009) resulting in increased NOx emissions. Lower NOx emissions obtained with AOME and their blends may also be due to their lower heating value and higher viscosity that leads to lower BTE and lower flame temperature. Higher NOx emission with diesel may be attributed to quicker combustion rate yielding superior cylinder temperature at higher IOP. AOME have shortened premixed combustion and hence showed comparatively lower $\mathrm{NO}_{\mathrm{x}}$ emissions compared to diesel. Also it has lower heating value and higher viscosity compared to diesel that led to lower BTE. Lower adiabatic flame temperature and CN of AOME resulted into lower NOx emissions.

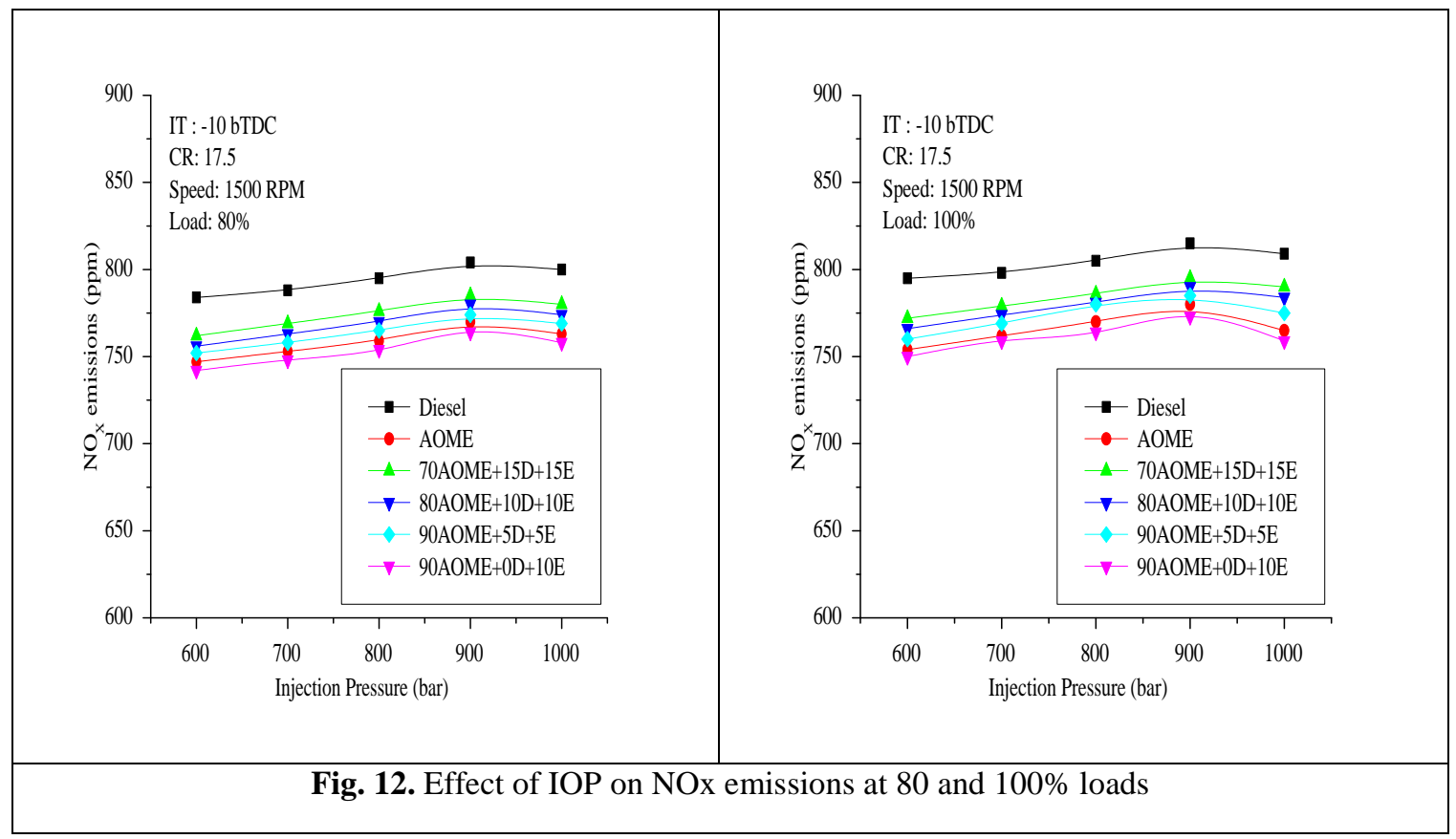

\section{Conclusion}

The present single cylinder CI engine was duly adapted to function in CRDI mode and was operated with AOME, and its blends with diesel and ethanol. Effect of IT and IOP on the performance of the CRDI engine fuelled with above fuel combinations has been carried out. From the exhaustive experimental study, following conclusions were drawn at both $80 \%$ and $100 \%$ loads.

$>$ AOME showed poor performance when compared to diesel in terms of lowered BTE, higher smoke, HC, CO emissions and lower NOx emissions. However blending AOME with ethanol and diesel (70AOME+15D+15E) showed promising performance and this blend can be used as an alternative fuel for diesel engine applications.

$>$ CRDI engine fuelled with AOME, diesel and ethanol showed increasing BTE at IT up to $10^{\circ}$ bTDC and outside this BTE lowered. Biodiesel exhibited weak performance with respect to lesser BTE compared to diesel.

$>\mathrm{HC}$ emissions diminished with slowed down IT even as CO and smoke emissions diminished considerably up to $10^{\circ}$ bTDC and amplified past the assumed IT. However NOx emissions amplified with superior IT normally.

$>$ With amplified IP, BTE increased up to 900 bar and beyond this pressure the BTE reduced due to system limitation.

$>\mathrm{HC}$ and $\mathrm{CO}$ emissions revealed comparable inclinations for both loads with minimum values at 900 bar and they amplified beyond 900 bar. $\mathrm{NO}_{\mathrm{x}}$ emissions grew with growth in IP.

$>$ Increasing ethanol and diesel in the AOME improved the performance drastically. Percentage of ethanol beyond $15 \%$ is not considered as it leads to phase separation.

Generally speaking it could be deduced that the developed CRDI single cylinder CI engine operated with AOME and its blends with diesel and alcohol worked satisfactorily and for a given blend of 70AOME+15D+15E the performance was similar to neat diesel operation. This experimental work showed the capability of AOME and its blends with diesel to substitute diesel that is the requirement of the present day. 
The present work manly focuses on the effect of injection pressure and injection timing on the performance and emission features of CRDI engine fuelled with selected fuel combinations for different loads. Further research may be taken up to examine the influence of speed on the performance and emission characteristics of CRDI engine having similar fuel blend combinations.

\section{Nomenclature}

$\begin{array}{ll}\text { AOME } & \text { Acid Oil Methyl Ester } \\ \text { aTDC } & \text { after Top Dead Centre } \\ \text { bTDC } & \text { before Top Dead Centre } \\ \text { CC } & \text { Combustion Chamber } \\ \text { CRDI } & \text { Common Rail Direct Injection } \\ \text { CR } & \text { Compression Ratio } \\ \text { CO } & \text { Carbon Monoxide } \\ \text { FAME } & \text { Fatty Acid Methyl Ester } \\ \text { HC } & \text { Hydrocarbon } \\ \text { ID } & \text { Ignition Delay } \\ \text { IP } & \text { Injection Pressure } \\ \text { IOP } & \text { Injection Opening Pressure } \\ \text { IT } & \text { Injection Timing } \\ \text { NOx } & \text { Oxides of Nitrogen } \\ \text { PM } & \text { Particulate Matter } \\ \text { SOC } & \text { Start of Combustion } \\ \text { SOI } & \text { Start of Injection }\end{array}$

\section{References}

Al-Hassan M., Mujafet H. and Al-Shannag M., 2012, An experimental study of diesel-ethanol blend and on the performance of a diesel engine fuelled with diesel-biodiesel-ethanol blends, Jordan Journal of Mechanical and Industrial Engineering, Vol. 6, pp. 147-153.

Armas O., Hernandez J.J., Cardenas M.D., 2006, Reduction of diesel smoke opacity from vegetable oil methyl ester during transient operation, Fuel, Vol. 85, pp. 2427-2438.

Bakar R.A., Semin and Ismail A.R. 2008, Fuel injection pressure effect on performance of direct injection diesel engines based on experiment, American Journal of Applied Sciences, Vol. 5, No. 3, pp. 197-202.

Fernando S., Hanna M., 2004, Development of novel biofuel blend using ethanol-biodiesel-diesel micro-emulsions, Fuel 2004, Vol. 18, pp. 1695-1703.

Grimaldi C.N., Postrioti L. and Battistoni M., 2002, Common rail HSDI engine combustion and emissions with fuel/ bio-derived fuel blends, 2002-01-0865, pp. 1453-1460.

Hulwan D.B., Joshi S.V., 2011, Performance and combustion characteristics of a multi-cylinder DI diesel engine running dieselethanol-biodiesel blends of high ethanol content, Applied Energy, Vol. 88, No. 12, pp. 5042-5055.

Hwang J., Qi D., Jung Y., Bae C., 2014, Effect of injection parameters on the combustion and emission characteristics in a common-rail direct injection diesel engine fuelled with waste cooking oil biodiesel, Renewable Energy, Vol. 63, pp. 9-17.

Jitendra N.G., Tarun G., Avinash K.A., 2012, Composition and comparative toxicity of particulate matter emitted from a diesel and biodiesel fuelled CRDI engine, Atmospheric Environment, Vol. 46, pp. 472-81.

Kulkarni B.M., Pujar B.G., Shanmukhappa S, 2008, Investigation of acid oil as a source of biodiesel, Indian Journal of Chemical Technology, Vol. 15, pp. 467-471.

Kwanchareon P., Luengnaruemitchai A., Jai-ln S., 2007, Solubility of diesel-biodiesel-ethanol blend, its fuel properties and its emission characteristics from diesel engine, Fuel, Vol. 86, pp. 1053-1061.

Lee C.S., Park S.W., and Kwon S.I., 2005, An experimental study on the atomization and combustion characteristics of biodieselblended fuels, Energy Fuels, Vol. 19, No. 5, pp. 2201-2208.

Lešnik L., Vajda B., Žunic Z., Škerget L., Kegl B., 2013, The influence of biodiesel fuel on injection characteristics, diesel engine performance, and emission formation, Applied Energy, Vol. 111, pp. 558-70.

Leung D, Luo Y, Chan T, 2006, Optimization of exhaust emissions of a diesel engine fuelled with biodiesel, Energy Fuels, Vol. 20, pp. 1015-1023.

Mueller C.J., Boehman A.L., and Martin G.C., 2009, An experimental investigation of the origin of increased NOx emissions when fuelling a heavy-duty compression-ignition engine with soy bio-diesel, SAE 2009-01-1792.

Monyem A., Gerpen J.H., Canakci M., 2001, The effect of timing and oxidation on emissions from biodiesel-fuelled engines, Trans ASAE 2001, Vol. 44, pp. 35-42.

Mueller C. J., Boehman A.L, Martin G., 2009, An experimental investigation of the origin of increased NOx emissions when fuelling a heavy duty compression ignition engine with soy biodiesel, SAE paper 2009-01-1792. 
Musa N.A., Teran G.M., Yaman S.A., 2016, Emission characterisation of diesel engine run on coconut oil biodiesel its blends and diesel, Journal of Applied Sciences and Environmental Management, Vol. 20, No. 2, pp. 303-306.

Pan J., Yang W., Chou S., Li D., Xue H., Zhao J., 2012, Spray and combustion visualization of bio-diesel in a direct injection diesel engine, Thermal Science, 107-111.

Pundir B.P., 2007, Engine emissions: Pollutant formation and advances in control technology, Alpha Science International Ltd.

Sayin C., Ilhan M., Canakci M., Gumus M., 2009, Effect of injection timing on the exhaust emissions of a diesel engine using diesel methanol blends, Renewable Energy, Vol. 34, pp. 1261-1269.

Senatore A., Cardone M., Buono D., 2008, Combustion study of a common rail diesel engine optimized to be fueled with biodiesel, Energy \& Fuels, Vol. 22, No. 3.

Wloka J.A., Pflaum S., Wachtmeister G., 2010, Potential and challenges of a 3000 bar common rail injection system considering engine behaviour and emission level, SAE International Journal of Engines, Vol. 3, pp. 801-813.

Wloka J.A., Potsch C., Watchmeister G., 2011, Injection spray visualization for 3000 bar diesel injection, ILASS-Europe Portugal, 18.

Yakup I., Duran A., 2003, Effect of fuel cetane number and injection pressure on a DI diesel engine performance and emissions, Energy Conversion \& Management, Vol. 44, pp. 389-397.

Ye P., Boehman A.L., 2011, An investigation of the impact of injection strategy and biodiesel fueling on engine NOx and particulate matter emissions with a common rail turbocharged DI diesel engine, Fuel, Vol. 97, pp. 476-488.

\section{Biographical notes}

S. Rajesh is currently working as Assistant Professor, Department of Mechanical Engineering, Bapuji Institute of Engineering and Technology, Davanagere 577004, with teaching experience of 19 years and industrial experience of 2 years, respectively. His area of research is renewable biofuels for internal combustion engines. He has published three international journal papers and two national and international conference papers.

B. M. Kulkarni is currently working as Professor in Chemical Engineering Department, Bapuji Institute of Engineering and Technology, Davanagere - 577004, with teaching experience of 25 years and industrial experience of 05 years, respectively. He has research experience of 08 years and his areas of research are biofuel development and biotechnology. He has published 19 international journal papers and 12 national and international conference papers.

S. Kumarappa is currently Professor and Head of Department of Mechanical Engineering, Bapuji Institute of Engineering and technology, Davanagere - 577004. He has 23 years of teaching experience with 10 years of research experience. His research areas include electronic engine management and alternative fuels for IC engines. He has published 25 international journal papers and 31 national and international conference papers.

N. R. Banapurmath is currently Professor and Head (Centre for Material Science) and Professor, Department of Mechanical Engineering , KLE Technological University, BVB college of Engineering and Technology, Hubballi - 580031, with teaching experience of more than 24 years and research experience of 08 years, respectively. His main areas of research are Alternative and Renewable fuels for internal combustion engines and Nanotechnology for structural and energy applications. He has published 90 international journal papers and 70 conference papers (National and International). He has also published 08 titles on books and book chapters. He is a reviewer for many national and international journals.

Received January 2017

Accepted March 2017

Final acceptance in revised form April 2017 